\title{
KINEMATIC ANALYSIS AND TERTIARY EVOLUTION OF THE LESVOS OPHIOLITES AND METAMORPHIC SOLE (AEGEAN SEA, GREECE) D.MOUNTRAKIS ${ }^{1}$, E.THOMAIDOU ${ }^{1}$, N.ZOUROS ${ }^{2}$, A.KILIAS ${ }^{1}$
}

\begin{abstract}
In Lesvos Island, the ophiolites and the metamorphic sole are emplaced onto the Permo-Triassic continental margin rocks. New field data on the Tertiary kinematics distinguished three successive tectonic events that affected the Lesvos ophiolites and sole. The D1 compressional event took place in Late Eocene - Early Oligocene and produced several thrust sheets and their stacking over the continental margin. The thickening of the crust after the D1 event, was followed by an important extensional tectonic event (D2) in semi-ductile conditions in Oligocene-Early Miocene times, which produced the uplift process of the orogen and the lateral rejection of the tectonic nappes through large extensional semi-ductile faults of low angle (detachment faults) and caused the exhumation of the underlying continental margin rocks in the form of a tectonic window. This extensional tectonic event led to the thinning of the crust in the wider area of Lesvos and probably caused the Early Miocene volcanic activity. The last D3 extensional tectonic event, took place in brittle conditions and represents the neotectonic regime in Late Miocene-Recent times.
\end{abstract}

KEY WORDS: Tertiary tectonics; Ophiolites; metamorphic sole; uplift-exhumation; Lesvos Island; Greece.

\section{INTRODUCTION}

Ophiolites and metamorphic ophiolitic sole occur in Lesvos Island in the northeastern Aegean Sea. The ophiolitic rocks are separated in two main masses, both located in the southeastern part of the island. The western mass which is the larger in the area of Olympus Mt.-Polychnitos and the eastern (smaller one) in the Amali peninsula in the south of Mytilene town (fig.1).

The ophiolites of the two masses are thrust on a metamorphic sole and both of them are structurally emplaced onto the Permo-Triassic rocks.

Lesvos' Permo-Triassic rocks probably represent a continental margin, although there is still much argument regarding its origin. The origin and emplacement of Lesvos' ophiolites also remains uncertain and there is a doubt whether they belong to IRO or ERO ophiolitic suture of Greece, since Lesvos is an island and its connection to the geotectonic zones of Greek mainland is not observable.

In this paper we present new field data on the Tertiary kinematics of ophiolites and metamorphic sole of both the ophiolitic masses of Lesvos, based on the study of shear criteria and kinematic indicators.

\section{GEOLOGICAL FRAMEWORK OF LESVOS ISLAND AND REMARKS ON THE OPHIOLITES AND THE METAMORPHIC SOLE}

The geology of Lesvos comprises a basement composed by pre-alpine and alpine rocks, which is covered in its major part by post-alpine formations, mainly volcanic rocks of Miocene age. The basement is widely observable in the southeastern part of the island (fig.1).

According to the mapping of Hecht $(1972,1974)$, Lesvos' basement is divided into the following three major units, which are in tectonic contact: the schists and marbles of Carboniferous age, the schists, phyllites and marbles of Carboniferous-Triassic age, and the ultramafic rocks.

A considerably revised map has been proposed by Katsikatsos et al. (1986), including the following units. The autochthonous unit of Neopaleozoic to Triassic age, which consists of low-grade metamorphic rocks i.e.: mica schists, quartzites, calcitic schists, metasandstones and phyllites. A carbonate sequence, often more than $400 \mathrm{~m}$ thick, occurs in the upper parts of this unit. Although the origin of this autochthonous unit still remains undocumented, it is considered as a probable remnant of the Cimmerian continent, belonging to the Pelagonian geotectonic zone (Mountrakis et al. 1983, Katsikatsos et al. 1986, Papanikolaou 1999).

1. Department of Geology and Paleontology, School of Geology, University of Thessaloniki, GR-54006, Thessaloniki, Greece.

2. Natural History Museum of the Petrified Forest of Lesvos, Sigri, Lesvos. 

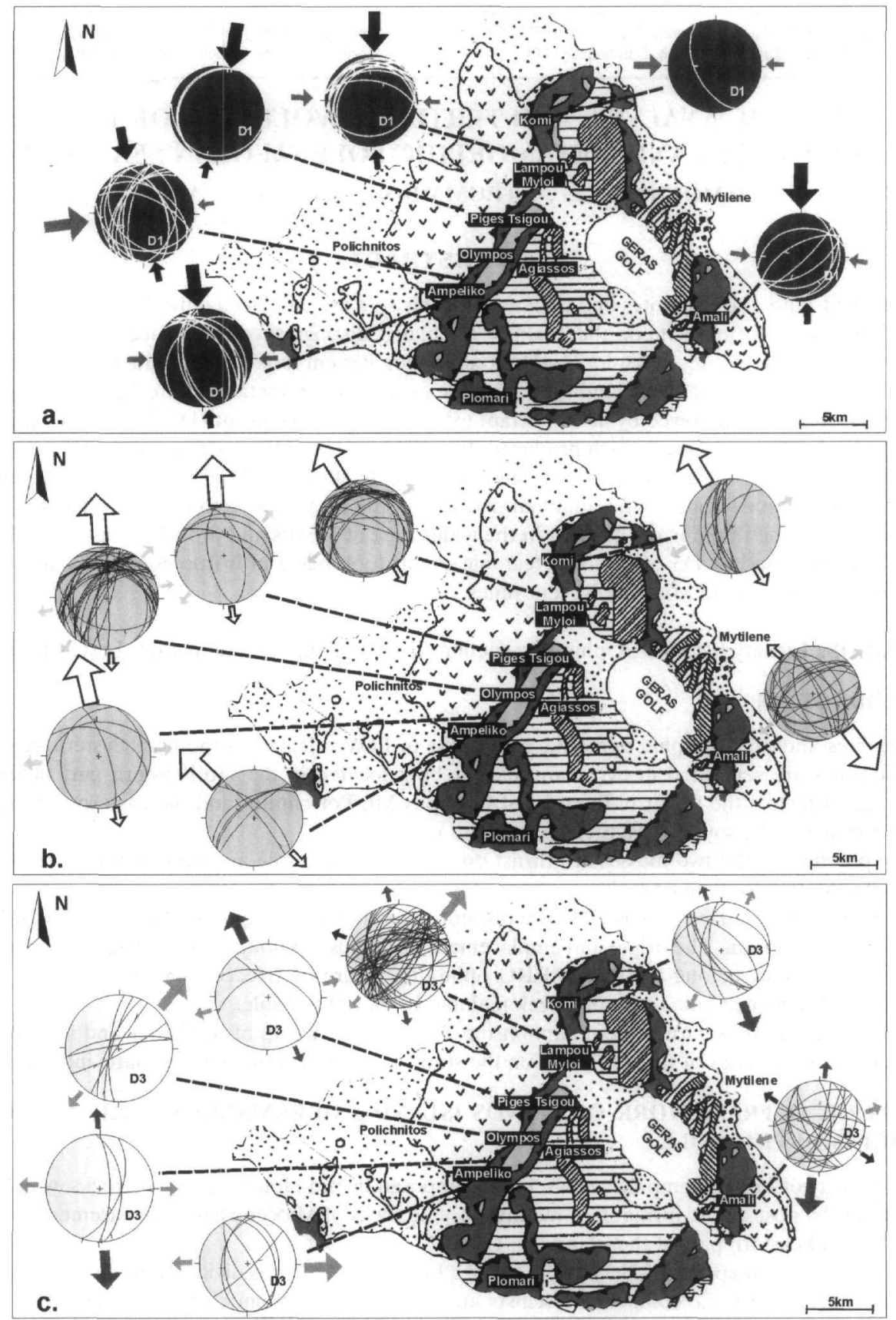

C.

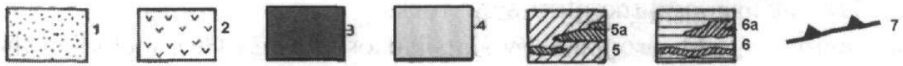

Fig. 1. Geological map of SE Lesvos (partly modified from Katsikatsos et al. 1986). 1: Early Miocene volcanics and Neogene-Quaternary sediments, 2: ophiolitic mass, 3: metabasites and metasediments of the metamorphic

sole, 4: Triassic carbonate rocks of the autochthonous unit, 5: Triassic schists and metasandstones of the autochthonous unit, 6: Neopaleozoic schists and metasandstones of the autochthonous unit, 5a-6a: intercalations of crystalline carbonate rocks of the autochthonous unit 7: tectonic contact. Diagrams of the main tectonic surfaces are plotted on the map, showing the directions of the stress-field for each tectonic event: a. D1 compressional event, b. D2 semi-ductile extensional event, c. D3 brittle extensional event. 
The allochthonous units of Lesvos are two tectonic nappes: $a$. the volcanosedimentary nappe and $b$. the ophiolitic nappe. The first one consists of metabasites and metamorphic sedimentary rocks of Triassic age. The metasediments are crystalline limestones, mica and amphibolitic schists, conglomerates, metapelites, calcitic phyllites, thin-bedded crystalline limestones to calcitic schists, reddish meta-cherts. Small ophiolitic bodies are found inside this unit. According to Katsikatsos et al. (1986), the metabasites are dominant in the upper parts of the unit and they have been characterized as "prasinites", while large outcrops of crystalline carbonate rocks have been considered as olistholiths within the metabasites (fig. 2). Although the rocks of the volcanosedimentary unit have been affected by a low-grade metamorphism (pumpellyite-actinolite-chlorite zone), the presence of glaucophane is also referred for some parts of the unit (Katsikatsos et al. 1986). In addition some parts of the volcanosedimentary tectonic nappe in the area of Vatera and Amali peninsula have been described as ophiolitic melanges (Tsikouras et al. 1994, Serelis 1995).

The Lesvos ophiolites consist mainly of serpentinized peridotites and dunites. In the base of the ophiolitic nappe along its contact with the volcanosedimentary nappe, small outcrops of the amphibolites and amphibolitic schists have been described as the "lower group" of the ophiolites, representing the metamorphic basic rocks of the ophiolitic sequence (Katsikatsos et al. 1986). Later they have been characterized as parts of the metamorphic sole by Serelis and Gartzos 1994, Hatzipanagiotou and Pe-Piper (1995), Gartzos et al. (1995).

The initial emplacement of both allochthonous units onto the Permo-Triassic carbonate rocks of the ancient continental margin took place in the Jurassic times (Papanikolaou 1999). According to our field observations on the Lesvos ophiolites and volcanosedimentary rocks, taking into account previous works on the Pindos, Vourinos (NW Greece), Albania and Turkey ophiolites carried out by different scientific groups (Jones \& Robertson 1991, Mountrakis et al. 1993a, 1993b, Dilek and Whitney 1997) and comparing their detailed descriptions of the typical metamorphic soles of the above mentioned ophiolitic masses with the Lesvos' rocks, we believe that both the allochthonous units of Lesvos represent remnants of an old oceanic crust. The amphibolites in the base of the ophiolites together with the meta-sediments and meta-volcanics of the "volcanosedimentary nappe" belong to the metamorphic sole and represent the old deep-sea sediments and the volcanic rocks associated to the ophiolitic sequence. Those sediments together with the upper parts of the ophiolitic rocks (basic rocks) entered in an intra-oceanic subduction zone, suffered a low-grade metamorphism and formed the metamorphic sole. The possible presence of glaukophane (Katsikatsos et al. 1986) might be evidence for a deeper dragging of the metamorphic sole inside the subduction zone as described for other metamorphic soles in similar cases (Dilek and Whitney 1997), but it is still under study. The large outcrops of the marbles inside the "volcanosedimentary nappe", are parts of the continental margin, together with the autochthonous unit of the basement, and they are in tectonic contact with the metasediments of the metamorphic sole (fig. 3).

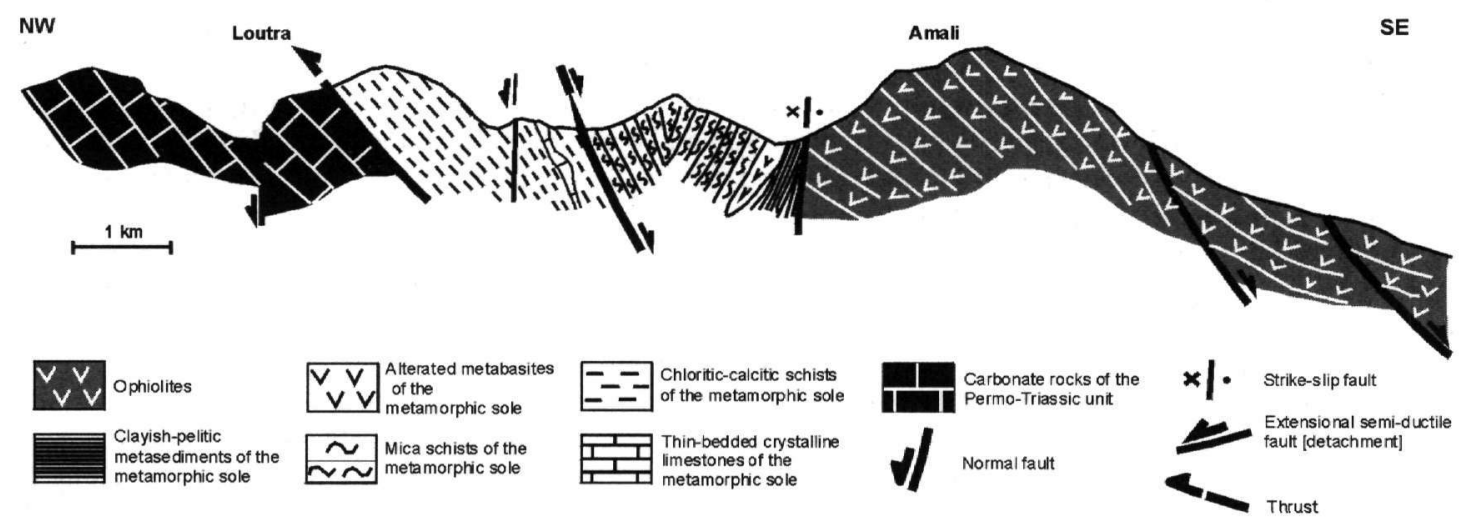

Fig. 2. Schematic geological cross section in the area of Amali peninsula, showing the tectonic emplacement of the ophiolitic nappe and metamorphic sole onto the carbonate rocks of the autochthonous unit. 

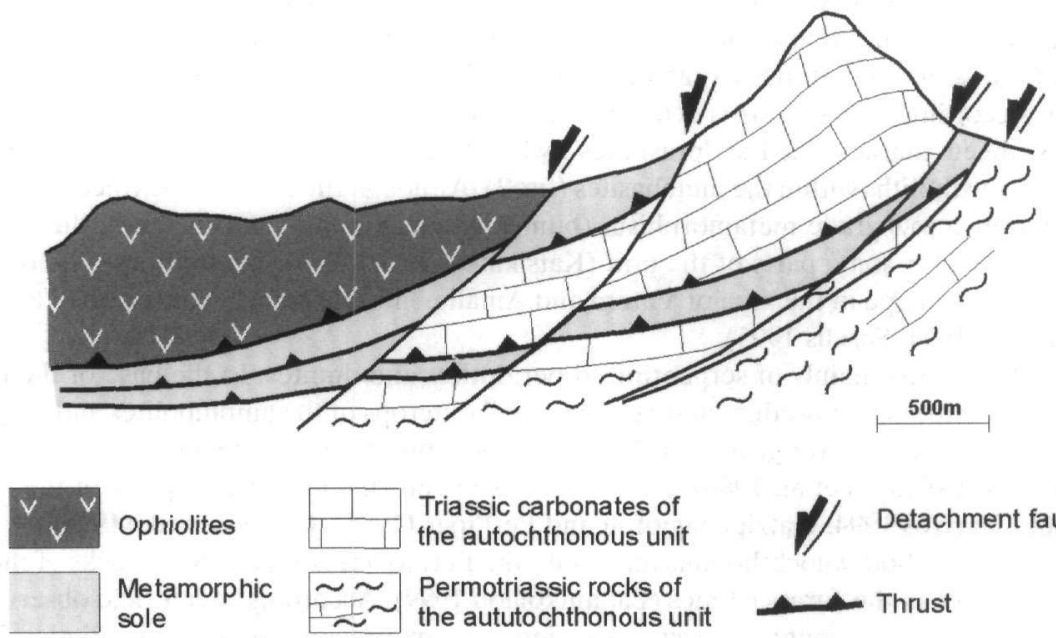

Triassic carbonates of the autochthonous unit

Permotriassic rocks of the aututochthonous unit

\section{Detachment faults} sole

Fig. 3. Schematic geological cross section in the area of Olympos Mt., showing the tectonic emplacement of the ophiolitic nappe and the metamorphic sole nappe onto the Triassic carbonate rocks of the autochthonous unit.

\section{GEOMETRY AND KINEMATIC ANALYSIS OF THE STRUCTURES}

The initial Mesozoic emplacement of the ophiolites and metamorphic sole onto the continental margin in Lesvos is hardly recognizable, due to the influence of the subsequent tectonic events. Thus, our investigation focused mainly on the Tertiary deformations and kinematics, in order to reconstruct the tectonic evolution of Lesvos' basement during Tertiary times.

Tectonic features of the ophiolites and the metamorphic sole, particularly microstructures, shear criteria and kinematic indicators used in the kinematic analysis in order to understand the sense of movement during the Tertiary tectonic events, which were distinguished in the field work. Quantitative analysis has also been used to evaluate our field observations, and the data were computed by the "Fault" software (Caputo 1989).

Three tectonic events, subsequent of the initial emplacement of the ophiolites onto the continental margin, were distinguished after the kinematic analysis in both the ophiolites and metamorphic sole: a. a D1 compressional event, displayed by low-angle reverse faults and micro-folds, b. a D2 semi-ductile extensional event, indicated mainly by low-angle shear zones, c. a D3 brittle extensional event, displayed by high-angle normal faults.

The D1 compressional event is the first one observed in Lesvos ophiolites, since its tectonic features have later been influenced by the posterior extensional tectonics. Small scale folds in the metasediments of the metamorphic sole with NNW-SSE and NNE-SSW axes and small-scale low-angle reverse faults in both the ophiolites and sole, mainly trending ENE-WSW and dipping $15^{\circ}-25^{\circ}$ towards NNW or SSE are the main features of this compressional event in ductile to semi-ductile conditions (fig. 5a, 5b). However some strike-slip faults with reverse component trending particularly NE-SW and minor trending NW-SE but with higher dip-angles, have also been observed.

The direction of the paleostress field during the first compressional event, determined from the statistic elaboration of the tectonic surfaces and lineations, shows a relative dispersion. A N-S direction of the compression is the dominant for the areas of Amali, Lampou Myloi, Piges Tsigou and Ampeliko (mainly in the rocks of the metamorphic sole, south of Ampeliko village). Kinematic indicators and shear criteria observed along the reverse faults, show the sense of movement mainly to the South. However, a secondary E-W direction of the compression with sense of shear to the East has also been determined, and it might be due to a subsequent local rotation of the material, or the compression field developed in two successive stages in different directions. Some of these structures could be inherited from the initial emplacement of the ophiolitic nappe, but there is no evidence for a possible connection with the tectonic features of the initial emplacement. The compressional structures are dominant in the area of Ampeliko, where they are very well preserved both in the ophiolitic rocks and the metamorphic sole. The secondary E-W compression is identified mainly in the ophiolitic rocks near their contact with the metamorphic sole, north of Ampeliko village (fig. 1a). 
The most impressive structures in both Lesvos' ophiolites and metamorphic sole are major and minor extensional tectonic features, which are the result of an important D2 extensional tectonic event. Elongation of competent ultramafic bodies and asymmetric boudins are the most common minor extensional features in the ophiolites and the metasediments of the sole. A well defined stretching lineation in both serpentinites and metasediments, is also associated with the minor extensional shear features. All these fabrics indicate a semiductile deformation, common for the ophiolites and metamorphic sole, which took place after the previous compressional tectonic event, since the extensional structures clearly affected the thrust surfaces of the D1 event. The D2 event displays major shear zones, mainly of low-angle, typical detachment faults, on which the slipping of the ophiolitic mass took place during the stage of the rejection of the tectonic nappes after the thickening and uplift of the continental crust (fig. 5). The direction of the D2 extensional stress-field is almost N$\mathrm{S}$ to NW-SE in all the areas of the Lesvos ophiolites and sole. In the western part of the ophiolites, that is in the areas of Lampou Myloi, Olympos, Ampeliko e.t.c., kinematic indicators observed in the shear microstructures show sense of movement to the N or NNW, while in the Eastern part the main movement is to the S. For this extensional semi-ductile event, a secondary NE-SW direction derived as well, which some times varies to ENEWSW and possibly is due to a local rotation of the material, but it is still under investigation (fig. 1b).

The D3 tectonic event represents the Neotectonic regime in the North Aegean area, in clear brittle conditions, which caused high-angle normal faults affecting the older structures of both previous D1 and D2 tectonic events. Typical pictures of small-scale, steeply dipping, normal faults, cutting the very low-angle shear zones of the D2 semi-ductile detachments, are clearly observed in the areas of Lampou Myloi, Olympos and Amali (fig. 5d). Additionally, some very important normal faults of the D3 event in kilometric scale, created the recent morphology of Lesvos Island, producing high depressions and grabens. The direction of this extensional stressfield, appears in the paleostress analysis with a great dispression (fig. 1c), because the D3 extensional tectonic event probably reflects the three neotectonic brittle phases, which has been determined for the wider North Aegean area, having different directions (Mercier et al. 1989, Pavlides et al. 1990, Dotsika et al. 1995). According to these references, the fist neotectonic phase occurred in Late Miocene and caused E-W to ENE-WSW trending stike-slip faults, the second one produced NW-SE trending normal faults, as well as NNE-SSW trending strike-slip faults during Pliocene, and the last one occurred in a N-S direction, produced E-W trending normal faults and reactivated pre-existing structures.

\section{CONCLUSIONS FOR THE TECTONIC EVENTS AND TECTONIC EVOLUTION OF THE LESVOS OPHIOLITES AND RELATED UNITS}

The relative dating of the three tectonic events, based on the influences between their structures, defined the above mentioned succession of the D1, D2, D3 tectonic process, which probably took place after the initial emplacement of the ophiolites and metamorphic sole onto the Permotriassic continental margin carbonates, because no relation of these tectonic features with the Jurassic emplacement process has been observed.

The last D3 extensional tectonic event, representing the neotectonic regime in Late Miocene-Recent times, has already been defined by Mercier et al. (1989). Since the structures of the compressional D1 event and the extensional D2 event have not affected the Early Miocene volcanic rocks of Lesvos Island, they might took place in pre-Miocene times. Taking into account analogous tectonic studies in the Vourinos, Pindos and Albania ophiolites (Mountrakis et al. 1993a, b), as well as in other areas of Northern Greece (Kilias and Mountrakis 1998, Kilias et al. 1999), suggesting similar tectonic features and succession, we believe that the D1 compressional event took place in the Tertiary (Late Eocene to Early Oligocene), and the D2 extensional event in Oligocene-Early Miocene times.

The D1 compressional tectonic event led to the forming of several thrusts and nappes, and their stacking over the continental margin. This D1 event was also responsible for the tectonic capture of the carbonate rocks inside the formations of the metamorphic sole during the compressional process (fig. $4 \mathrm{~b}$ ).

The thickening of the crust after the D1 compressional event, was followed by an important extensional tectonic event (D2) in semi-ductile conditions, which produced the uplift process of the orogen and the lateral rejection of the tectonic nappes through large extensional semi-ductile normal faults of low-angle (detachment faults), which caused the revealing of the underneath rocks and led to the exhumation of the underlying continental margin in the form of a tectonic window. This extensional tectonic event led to the thinning of the crust in the wider area of Lesvos and was probably associated to the start of the Early Miocene volcanic activity (fig. 4c).

During the recent neotectonic activity in Late Miocene-Quaternary times (neotectonic phases grouped in D3 event), brittle high-angle normal faults cut and depressed the central part of the autochthonous unit of the basement, forming the tectonic graben of the Geras Golf (fig. 4d). 


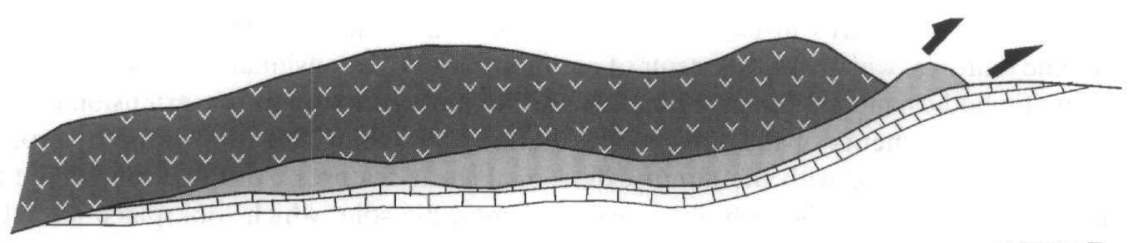

a. Jurassic - initial emplacement

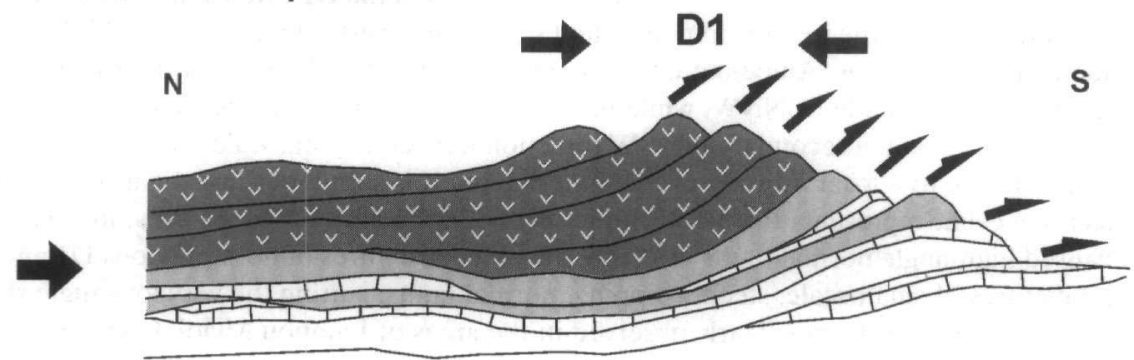

b. Late Eocene-Early Oligocene

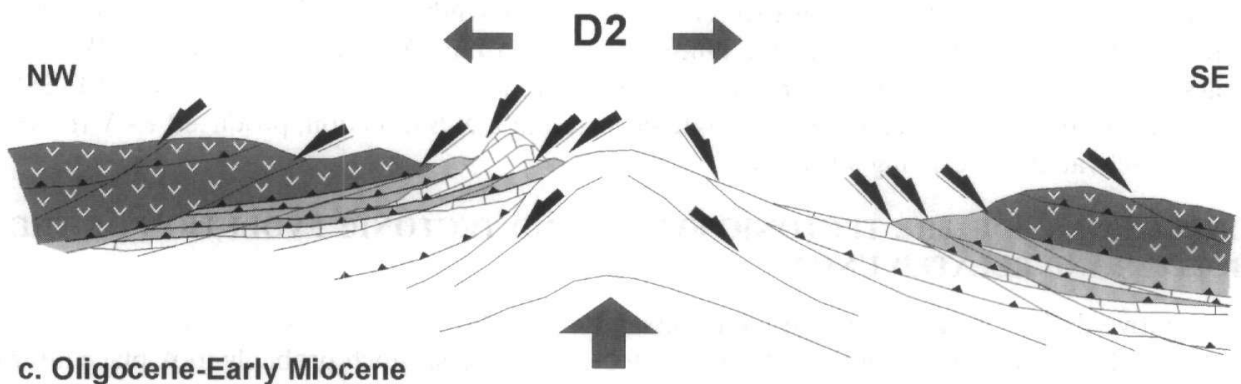

c. Oligocene-Early Miocene

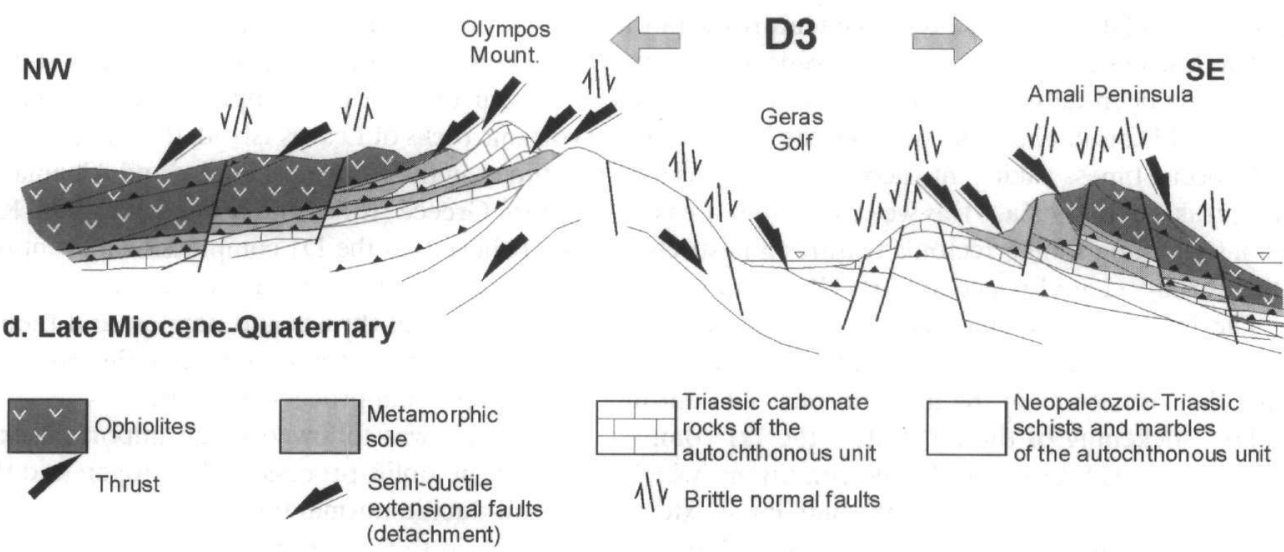

Fig. 4. Schematic tectonic evolution of Lesvos basement, subsequent of the initial emplacement of the ophiolitic and metamorphic sole nappes: a. initial emplacement of the ophiolites and metamorphic sole during Jurassic, b. Late Eocene-Early Oligocene D1 compressional event causing the stacking of the thrust sheets, $c$. Oligocene-Early Miocene D2 semi-ductile extensional event causing the uplift and orogenic collapse, $d$. D3 brittle extensional event, causing the neotectonic grabens. 

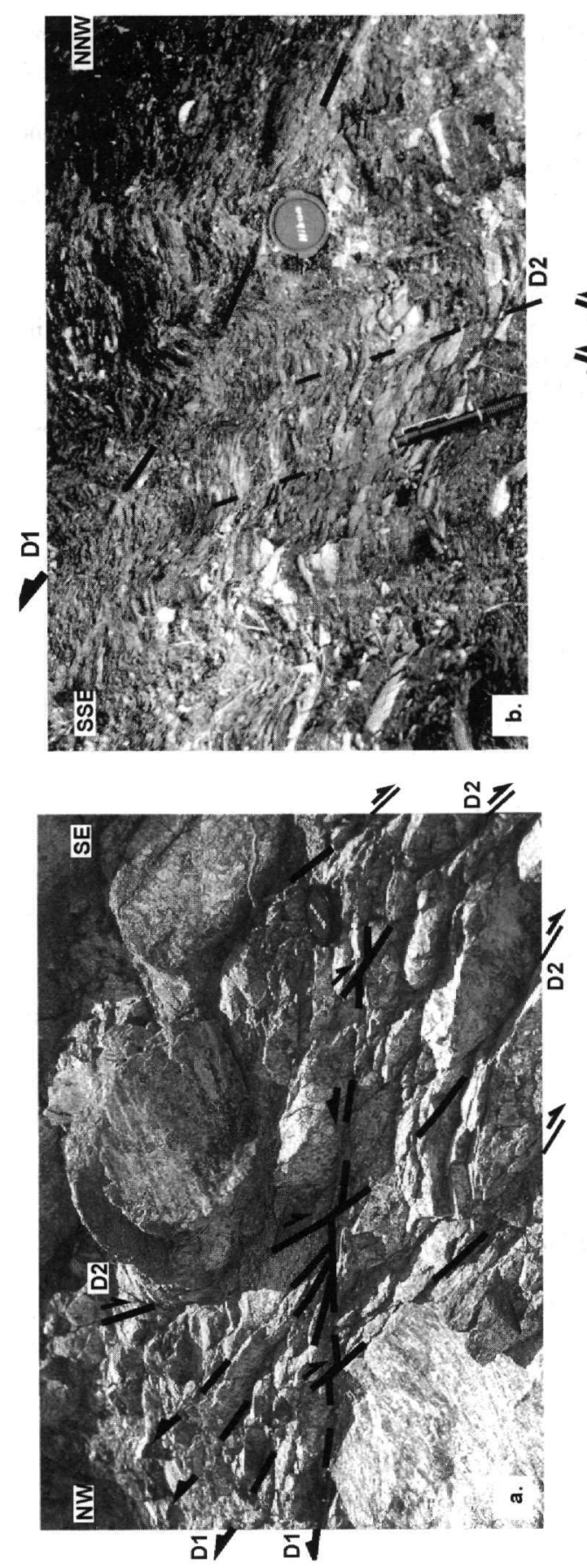
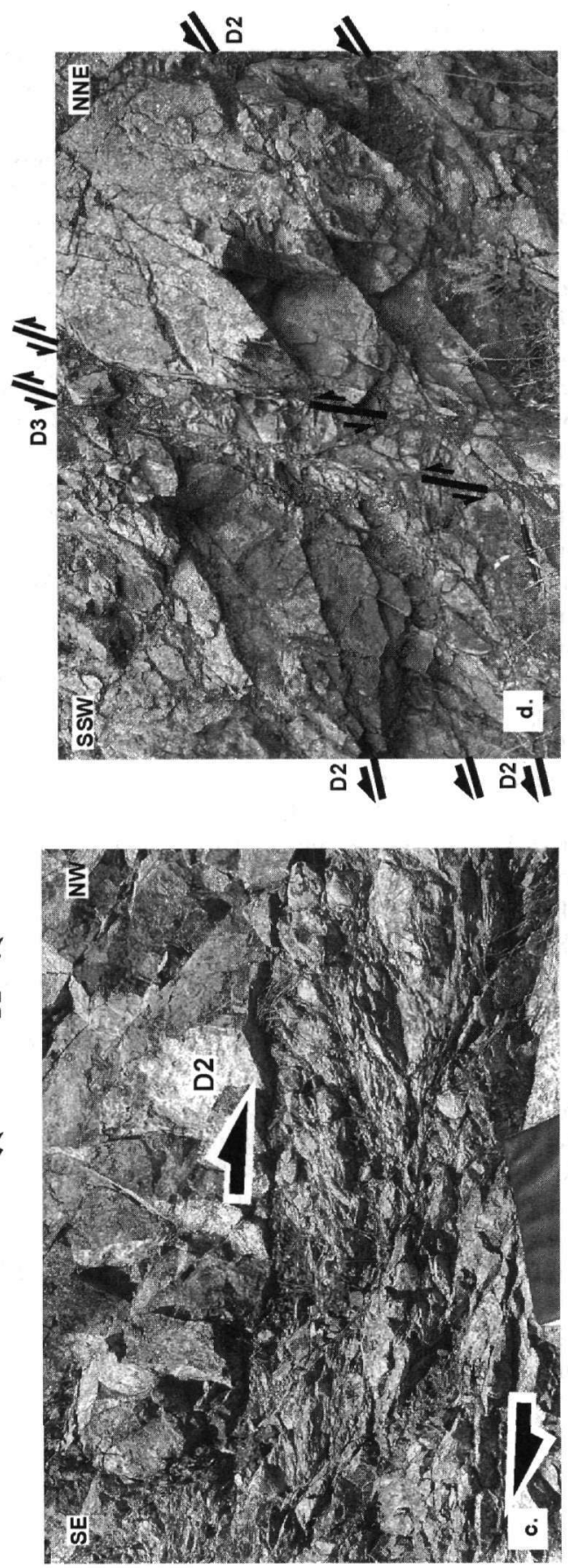

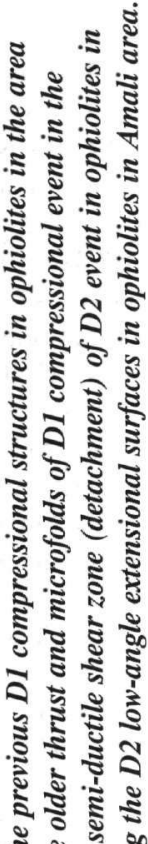

ฐ ฐ ะ ะ

. รัँ ₹ วิ กิ इ के इ ริ) ๙ิ ปี ฐี จ $\cong 0$ ชิธี ㄱำ คิ ป है म० 


\section{REFERENCES}

CAPUTO R. (1989). FAULT: a programme for structural analysis. University of Florence, Diskette and manual, $54 \mathrm{pp}$.

DILEK Y. and WHITNEY D. (1997). Counterclockwise P-T-t trajectory from the metamorphic sole of a NeoTethyan ophiolite (Turkey). Tectonophysics, vol.280, pp.295-310.

DOTSIKA E., FYTIKAS M., MOUNTRAKIS D., PAPAGEORGIOU F. and ZOUROS N. (1995). Geothermal exploration in Mytilene area (Lesvos isl. Greece). Proceedings of the World Geothermal Congress 1995, vol.2, pp.989-994.

GARTZOS E., SERELIS K. and MIGIROS G. (1992). Study of the Amphibolitic Rock Unit of Lesvos Island (Greece). Annales Geologiques Des Pays Helleniques, 1e Serie, T. XXXV, pp. 489-504.

HATZIPANAGIOTOU K. and PE-PIPER G. (1995). Ophiolitic and sub-ophiolitic metamorphic rocks of the Vatera area, southern Lesvos (Greece): geochemistry and geochronology. Ophioliti, vol.20(1), pp.17-29.

HECHT J. (1972). Geological map "Plomari-Mytilini" sheet, scale 1:50.000. I.G.M.E.

HECHT (1974). Geological map "Polichnitos" sheet, scale 1:50.000. I.G.M.E.

JONES G. and ROBERTSON A. (1991). Tectono-stratigraphy and evolution of the Mesozoic Pindos ophiolite and related units, northwestern Greece. Journal of the Geological Society, London, vol.148, pp.267-288.

KATSIKATSOS G., MIGIROS G., TRIANTAPHYLLIS M. and METTOS A. (1986). Geological structure of the internal Hellenides (E. Thessaly - SW. Macedonia, Euboea-Attica-Northern Cyclades Islands and Lesvos). I.G.M.E. Geological and Geophysical Research, Sp.Issue, pp.191-212.

KILIAS A., FALALAKIS G. and MOUNTRAKIS D. (1999). Cretaceous-Tertiary structures and kinematics of the Serbomacedonian metamorphic rocks and their relation to the exhumation of the Hellenic hinterland (Macedonia, Greece). Int. Journ. Earth Sciences, vol.88, pp.513-531.

KILIAS A. and MOUNTRAKIS D. (1998). Tertiary extension of the Rhodope massif associated with granite emplacement (Northern Greece). Acta Vulcanologica, vol.10(2), pp.331-337.

MERCIER J., SOREL D., VERGELY P. and SIMEAKIS K. (1989). Extentional tectonic regimes in the Aegean basins during the Cenozoic. Basin Res., vol.2, pp.49-71.

MOUNTRAKIS D., SAPOUNTZIS E., KILIAS A., ELEFTHERIADIS G. and CHRISTIFIDES G. (1983). Paleogeographic conditions in the western Pelagonian margin in Greece during the initial rifting of the continental area. Can. J. Earth Sci., vol.20, pp.1673-1681.

MOUNTRAKIS D., KILIAS A. and ZOUROS N. (1993a). Kinematic analysis and Tertiary evolution of the Pindos-Vourinos ophiolites (Epirus-Western Macedonia, Greece). Proc.6th congress, Bull.Geol.Soc.Greece, vol.XXVIII/1, pp.111-124.

MOUNTRAKIS D. SHALLO M., KILIAS A., VRANAI A., ZOUROS N. and MARTO A. (1993b). Post emplacement tectonics and kinematic analysis of the Albanian ophiolites. Proc. 6th congress, Bull. Geol. Soc. Greece, vol.XXVIII/1, pp. 137-150.

PAPANIKOLAOU D. (1999). The Triassic ophiolites of Lesvos Island within the Cimmeride orogene event. EUG 10, Symposium D06: Inter-Relations between Palaeotethys and Neotethys in Europe and Asia, p.315.

PAVLIDES S., MOUNTRAKIS D., KILIAS A. and TRANOS M. (1990). The role of strike-slip movements in the extensional area of the Northern Aegean (Greece). A case of transtensional tectonics. In: M.Boccaletti \& A.Nur (Ed.) Active and Recent Strike-slip Tectonics, Ann. Tectonicae, vol.4(2), pp.196-211.

SERELIS K. and GARTZOS E. (1994). The ultra-mafic rocks of Lesvos Island. Bull. Geol. Soc. Greece, vol.30/ 3, pp.113-124.

SERELIS K. (1995). Investigation of the ophiolites of Lesvos Island. Ph.D Thesis, Agricultural Univ. Athens, 241 pp.

TSIKOURAS B., BELTAS P. and HATZIPANAGIOTOU K. (1994). Petrography and geochemistry of basaltic rocks from the Vatera ophiolitic melange (S.Lesvos, N.Aegean). Bull. Geol. Soc. Greece, vol.30/3, pp.103112. 